\title{
The Effect Of Church And Service On Ethics Education: An Experiment With Accounting Students
}

David S. Christensen, (Email: christensend@suu.ed), Southern Utah University David Rees, (Email: rees@suu..edu), Southern Utah University

Jeff Barnes, (Email: barnes@suu.edu), Southern Utah University

\begin{abstract}
Recent highly-publicized scandals involving accounting ethical failures have renewed recommendations to include ethics education in the accounting curriculum. Hundreds of studies confirm that the ability of students to recognize ethical dilemmas and make moral judgments improves during the college years. However, pre-existing conditions that may influence the improvement are unclear. Using a pretest-posttest control group design and a survey instrument of 25 ethics vignettes, we measured the effect of ethics education on the moral judgment of 81 accounting students over one semester. Results showed that the effectiveness of short-term accounting ethics education is influenced by prior participation in church and service activities. Students with participation showed significant improvement in moral judgment; students without participation did not improve. These results suggest that accounting students with prior church and service activities are more likely to be influenced by ethics education.
\end{abstract}

\section{INTRODUCTION}

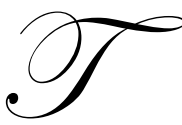

he need for a renewed emphasis in accounting ethics education is apparent. The financial scandals at Enron, WorldCom, Adelphia, Tyco, HealthSouth, Global Crossing, and other companies have adversely affected the reputation of the accounting profession (Wei 2002). Congress reacted with the Sarbanes-Oxley Act of 2002, which among other reforms, mandates ethical changes pertaining to auditor independence (Title II), and a code of ethics for financial officers (Title IV). State Boards of Accountancy are also reacting by revising ethics requirements for both current and new entrants (Thomas 2004). Recognizing that accounting professionals are first exposed to accounting ethics as students, educators have also begun to re-examine ethics education in the accounting curriculum.

McDonald and Donleavy (1995) review common objections to teaching business ethics. Perhaps the most frequent one is that ethics courses are unlikely to affect value or attitudinal change in college students because "values and attitudes are created over time as a result of cultural, family, and religious affiliations" (p. 841). On this issue they conclude that "the evidence to date suggest that courses can be a means of achieving ethical awareness and sensitivity in students" (p. 839). In addition, we find the observation of Hanson, described by McDonald and Donleavy as an "experienced teacher in the field of ethics," to be particularly insightful. He suggests that the goals of ethics education should be to help well-intentioned business students "to manage the strength of their own characters, to deal effectively with predictable ethical challenges in any business career, and in their role as managers, to create a supportive ethical environment for their subordinates (Hanson 1987: 11).

With these goals in mind, we favor the recommendation of Piper et al. (1993), who conclude that ethics not only can be taught, but must be taught at the college level. In the Literature Review that follows, we examine the evidence that generally supports the effectiveness of teaching business ethics to college students. This literature reveals various ways of teaching ethics to accounting students, and identifies factors outside the classroom, such as religiosity and service, that may promote moral development. The Methodology section describes our experiment to 
test the effectiveness of ethics education in several accounting courses, with church activity and service experience as moderating variables. The Results section reports that the ethics education was effective in improving the moral judgment of accounting students in one semester, but only for those reporting prior involvement in church or service activities. A discussion of the implications to accounting ethics education and our recommendations conclude the paper.

\section{LITERATURE REVIEW}

\section{Can Ethics Be Taught To College Students?}

The theoretical background of accounting ethics research rests largely on the work of Lawrence Kohlberg and James Rest, developmental psychologists. Kohlberg $(1979,1984)$ noted that as children grow they advance through definite stages of moral development. From his observations and tests, he identified six specific stages of moral development through which human beings consecutively progress. In the first two stages ("pre-conventional"), people make moral decisions based on rewards and punishments. In the third and fourth stages ("conventional"), people make moral decisions based on society's expectations and the respect for rules and laws. In the fifth and sixth stages ("post-conventional"), people make moral decisions based on logical application of universal moral principles despite legal or social implications.

Using Kohlberg's theory, Rest (1979) developed the Defining Issues Test (DIT), a paper-and-pencil test designed to measure moral judgment. The DIT consists of short ethical dilemmas with questions after each one. Based on the answers, a respondent is categorized into one of the three levels of moral development, and given a "P score" that represents the degree to which the answers fit the post-conventional level of Kohlberg's theory.

The DIT has been used in over 500 published articles (reviewed by Bebeau and Thoma 2003), including studies involving accounting students (e.g., Armstrong 1987 and 1993, Ponemon 1990, Thorne 2000). These studies strongly confirm that ethics can be taught to college students. For example, Rest and Thoma (1985) tracked the moral development of students from the end of high school to six years beyond high school. They found that DIT scores increased for those attending college but were stable for those who did not attend college.

\section{Factors That Promote Ethical Awareness In College}

While the empirical evidence is strong that the college experience enhances moral judgment, it is not clear as to what it is in the college experience that stimulates it. Possible causal factors include the type of institution, the academic discipline, the curriculum within the discipline, the amount of time devoted to ethics education, and factors outside the classroom, such as involvement in religious or service activities.

\section{Type of Institution}

Several studies have shown that liberal arts colleges, as compared to other types of colleges and universities, tend to be more conducive to fostering the development of moral judgment, although no firm evidence exists as to why this is so (Pascarella and Terenzini, 1991, McNeel, 1994; Good and Cartwright, 1998).

\section{The Academic Discipline}

The evidence that different academic disciplines may affect moral judgment differently is mixed. St. Pierre et al. (1990) found that students majoring in accounting and other business disciplines showed lower levels of moral judgment than students majoring in psychology, math, and social work. Jeffrey (1993) hypothesized that students who majored in liberal arts would achieve a higher level of moral judgment as compared to students who majored in business or accounting, where there is a supposed emphasis on "hard-and-fast rules." Somewhat surprisingly, Jeffrey's research did not support his hypothesis. Instead, Jeffrey found that the ethical development of accounting students was higher than the ethical development of other students in lower-division classes and remained so through the senior 
year. Snodgrass and Behling (1996) found no difference in the moral judgment between business and non-business majors.

\section{Time Devoted To Ethics}

Following an analysis of 55 studies, Rest (1986) concluded that interventions of longer than twelve weeks had no more impact on moral judgment development than interventions of three to twelve weeks, and that interventions of less than three weeks did not increase the DIT score. Armstrong (1993) advocates multiple interventions, finding that moral judgment scores are greater for students who are exposed to a class on general ethics followed by an accounting class where ethics is interwoven in the course material, and then a capstone course on accounting ethics. Hence, it appears that repeated exposure to ethics may be superior in developing moral judgment as compared to one-time exposure.

\section{Nature Of The Course Or Experience}

Several studies have investigated the effects that a specific course or type of experience may have on moral judgment. Among them are studies on general education courses (Mustapha and Seybert 1989), ethics courses (Armstrong 1993, Ponemon 1993, Boss 1994), a freshman colloquium on psychosocial issues (Tennant 1991), participation in service learning (Boss 1994; Gorman et al., 1994), an outdoor education program (Smith and Bunting 1999), and religiosity (Conroy and Emerson 2004). Of note is that virtually all of these approaches were effective in promoting moral judgment. Ferrell et al. (2005:109) believe that it is "experience in resolving moral conflicts [that] accelerates an individual's progress in moral development." This belief is also postulated by Rest and Deemer (1986) who state that "spending more time contemplating issues" is a key factor in promoting moral judgment (King and Mayhew, 2002:258).

\section{HYPOTHESES}

A review of this literature suggested three hypotheses. First, short-term accounting ethics education will increase the moral judgment of accounting students. The results of Kohlberg and others strongly support this expectation. Second, the effectiveness of the ethics education will be positively influenced by prior church attendance of the students. Third, the effectiveness of the ethics education will be positively influenced by prior service experience of the students.

The literature shows that factors outside the classroom can influence the effectiveness of ethics education in developing the moral judgment of college students. In an experiment with 850 students at two universities, Conry and Emerson (2004) reported that "religiosity" is a predictor of moral judgment among students. The proxy for religiosity was church attendance. Students with a higher frequency of church attendance had higher scores in moral judgment. This finding was consistent with other experiments (Siu et al. 2000, Smith and Oakley 1996, and Miesing and Preble 1985). In addition, the mixed results across the academic disciplines described above may be explained by prior experiences (e.g., church attendance and service) of the students.

Another factor that may influence the effectiveness of ethics education is prior service experiences of the students. For example, Weber and Glyptis (2000) concluded that community service-learning experiences improved moral judgment. In addition, Kohlberg's stage theory supports this expectation. Altruistic or service activities should help individuals mature from pre-conventional levels, where moral judgment is motivated by self-interest, to higher levels, where moral judgment is motivated by concern for others (conventional), or by a desire to follow universal ethical principles such as justice and equity (post-conventional, or "principled reasoning"). 


\section{METHODOLOGY}

\section{Experimental Design}

To test these hypotheses, we used a pretest-posttest control group design (Campbell and Stanley 1966) consisting of students in several accounting courses taken during the fall 2004 semester at a small western university. In this design, observations $(\mathrm{O})$ are made in the pretest (O1 and $\mathrm{O} 3)$, the experimental group is treated $(\mathrm{X})$, and subsequent observations ( $\mathrm{O} 2$ and $\mathrm{O} 4)$ are made on each group in the posttest.

\begin{tabular}{|lcrc|}
\hline Control Group & Pretest & & Post-test \\
\cline { 2 - 4 } Experimental Group & O1 & & O2 \\
\hline
\end{tabular}

Gain scores, defined as differences between the posttest and pretest observations, are computed (O2-O1, and O4-O3). A significant difference in gain scores between the groups $((\mathrm{O} 4-\mathrm{O} 3)-(\mathrm{O} 2-\mathrm{O} 1))$ implies that the treatment (i.e., the ethics training) caused the difference, assuming that other factors are properly controlled using randomization. Unfortunately, randomly assigning our students to each group was not practical. We recognize that the lack of randomization is a significant but common limitation inherent in experiments with students.

The following table summarizes selected demographics of the students in the experiment:

Table 1: Selected Demographics Of Students In The Experiment

\begin{tabular}{|l|c|c|c|c|c|c|}
\hline & \multicolumn{2}{|c|}{ Gender } & \multicolumn{3}{|c|}{$\begin{array}{c}\text { Sttended } \\
\text { Church? }\end{array}$} & \multicolumn{2}{c|}{ Service? } \\
\hline Group (Accounting Courses) & Male & Female & Yes & No & Yes & No \\
\hline Control (Principles, Tax, Intermediate II) & 17 & 4 & 17 & 4 & 14 & 7 \\
\hline Experimental (Mngt., Cost, Intermediate I, Systems, Audit) & 39 & 21 & 50 & 8 & 51 & 6 \\
\hline Total number of students & 56 & 25 & 67 & 12 & 65 & 13 \\
\hline
\end{tabular}

The results of hundreds of intervention studies involving ethics education show that the moral judgment of students can improve significantly. Thus, our expectation was that providing ethics education to our accounting students would improve their moral judgment. Gender, prior church attendance, and prior service involvement were included as variables that may influence effectiveness of ethics education. A difference due to gender is often reported in the ethics research, and is included here for that reason; we have no a priori rationale. Church attendance and service are factors outside the formal educational system that may influence moral judgment (Conroy and Emerson 2004, and Weber and Glyptis 2000).

The pretest was administered to all students during the first week of the semester. All of the students had already completed a course that covered ethical issues in business as freshmen or sophomores. The intervention was additional ethics education provided within each accounting course. The content of the ethics education depended on the course. In the systems and auditing courses, the professor reviewed ethical or moral philosophies, including egoism, utilitarianism, deontology, and virtue ethics. In the cost and management accounting courses the professor used end-of chapter ethics vignettes. For example, in cost accounting the vignettes typically focused on temptations to favorably bias an internal performance report for a supervisor. Classroom discussions focused on how to resolve the dilemmas, often by referring to standards of conduct for professional management accountants (Institute of Management Accounting 2000). In intermediate accounting, students developed a code of conduct for the course. The posttest was administered near the end of the semester.

\section{Hypothesis Testing}

Bedeau and Thoma (2003:9) report that "DIT scores show significant gains due to moral educational programs of more than three weeks." In addition, Ferrell et al. (2005:109) indicate that "according to his [Kohlberg's] 
model, as people progress through the stages of moral development, and with time, education, and experience, they may change their values and ethical behavior," and "experience in resolving moral conflicts accelerates an individual's progress in moral development." Accordingly, our expectation was that the moral judgment of students would improve after completing the ethics assignments over a 15 -week semester. To test this expectation, we computed the gain scores for each student (posttest - pretest), the mean gain scores for the control and experimental groups, and the difference in the mean gain scores of the groups (Campbell and Stanley 1966: 23).

The difference in the mean gain scores was tested using the Wilcoxon signed-rank test at an alpha of 0.05 (Sheskin 2000). A positive difference implied improvement. The formal hypotheses and interpretations are shown below. If the null hypotheses were rejected at an alpha of 0.05 , then the moral judgment of the students exposed to ethics assignments during the semester improved significantly.

\begin{tabular}{|cc|}
\hline $\begin{array}{c}\text { Hypotheses } \\
\text { Null: Difference } \leq 0\end{array}$ & $\begin{array}{c}\text { Interpretations } \\
\text { Alternative: Difference }>0\end{array}$ \\
$\begin{array}{c}\text { The moral judgment of the students did not improve } \\
\text { The moral judgment of the students improved }\end{array}$ \\
\hline
\end{tabular}

To measure the effect of the ethics education, we used the survey instrument developed by Conroy and Emerson (2004). It includes 25 vignettes taken from several validated questionnaires reported in the ethics research literature. (Although the DIT is more widely recognized, there is a fee for using it. The instrument we used was free.) The vignettes covered a variety of unethical behaviors, including expense padding, earnings manipulation for personal gain, fraud, tax evasion, bribery, and questionable safety, environmental, promotion, and employment practices.

After reading each vignette the students indicated the degree to which each behavior was ethically acceptable using a seven-point Likert scale, ranging from "always acceptable" (1), to never acceptable (7). The survey instrument appears in the appendix to this paper.

\section{RESULTS}

The ethics education improved the short-term moral judgment of the accounting students. As shown in Tables 2 and 3 and the related figures, the mean gain score of the control group was negative (-.08), the mean gain score of the experimental group was positive (0.07), and the difference in the mean gain scores was significantly positive $(0.15$, one-tailed $\mathrm{p}<0.003)$. These results are consistent with the results of other intervention studies, where the moral judgment of the experimental group increased significantly relative to the comparison group. The moral judgment of college students, including accounting majors, can be improved with ethics education.

These results were sensitive to differences in gender, church attendance, and involvement in service activities. As shown in the tables and figures, the moral judgment of males, students who reported regular prior church attendance, and students who reported a prior community service experience improved relative to the control group. The moral judgment of females, and students with no prior church attendance or service activity did not improve significantly relative to the control group. 
Table 2: Pretest, Post-Test, And Gain Scores

\begin{tabular}{|c|c|c|c|c|c|c|c|}
\hline \multicolumn{8}{|c|}{ Control Group } \\
\hline & & \multicolumn{2}{|c|}{ Pretest } & \multicolumn{2}{|c|}{ Post-test } & \multirow[b]{2}{*}{ Gain } & \multirow[b]{2}{*}{ S.Dev. } \\
\hline Category & $\mathbf{N}$ & Mean & S.Dev. & Mean & S.Dev. & & \\
\hline All & 525 & 5.13 & 1.844 & 5.05 & 1.845 & -0.081 & 1.612 \\
\hline Male & 425 & 5.03 & 1.850 & 5.00 & 1.857 & -0.034 & 1.619 \\
\hline Female & 100 & 5.53 & 1.772 & 5.25 & 1.789 & -0.280 & 1.577 \\
\hline Church & 425 & 5.12 & 1.840 & 5.06 & 1.806 & -0.055 & 1.610 \\
\hline No Church & 100 & 5.17 & 1.970 & 4.98 & 2.010 & -0.190 & 1.625 \\
\hline Service & 350 & 5.24 & 1.814 & 5.24 & 1.895 & -0.004 & 1.701 \\
\hline No Service & 175 & 4.90 & 1.89 & 4.67 & 1.683 & -0.234 & 1.409 \\
\hline \multicolumn{8}{|c|}{ Experimental Group } \\
\hline All & 1497 & 5.39 & 1.747 & 5.46 & 1.791 & 0.074 & 1.467 \\
\hline Male & 974 & 5.23 & 1.833 & 5.38 & 1.869 & 0.153 & 1.512 \\
\hline Female & 523 & 5.69 & 1.530 & 5.61 & 1.627 & -0.074 & 1.369 \\
\hline Church & 1247 & 5.41 & 1.738 & 5.55 & 1.741 & 0.141 & 1.390 \\
\hline No Church & 200 & 5.34 & 1.784 & 4.90 & 1.97 & -0.445 & 1.845 \\
\hline Service & 1272 & 5.34 & 1.759 & 5.49 & 1.778 & 0.145 & 1.391 \\
\hline No Service & 150 & 5.49 & 1.794 & 4.85 & 1.986 & -0.640 & 2.004 \\
\hline
\end{tabular}

Table 3: Difference In Gain Scores

\begin{tabular}{|l|c|c|c|c|c|}
\hline Category & Difference In Gain Score & Standard Error & Z & P & Sig. \\
\hline All & 0.155 & 0.076 & -2.728 & 0.003 & $*$ \\
\hline Male & 0.187 & 0.090 & -2.729 & 0.003 & $*$ \\
\hline Female & 0.206 & 0.153 & -1.592 & 0.056 & \\
\hline Church & 0.196 & 0.081 & -2.742 & 0.002 & $*$ \\
\hline No Church & -0.255 & 0.217 & -0.787 & 0.785 & \\
\hline Service & 0.149 & 0.088 & -2.057 & 0.020 & $*$ \\
\hline No Service & -0.406 & 0.190 & -2.123 & 0.983 & \\
\hline *one-tailed p $<0.05$ (Wilcoxon Signed-Rank Test) & \multicolumn{5}{|l|}{} \\
\hline
\end{tabular}


Figure 1: Control Group

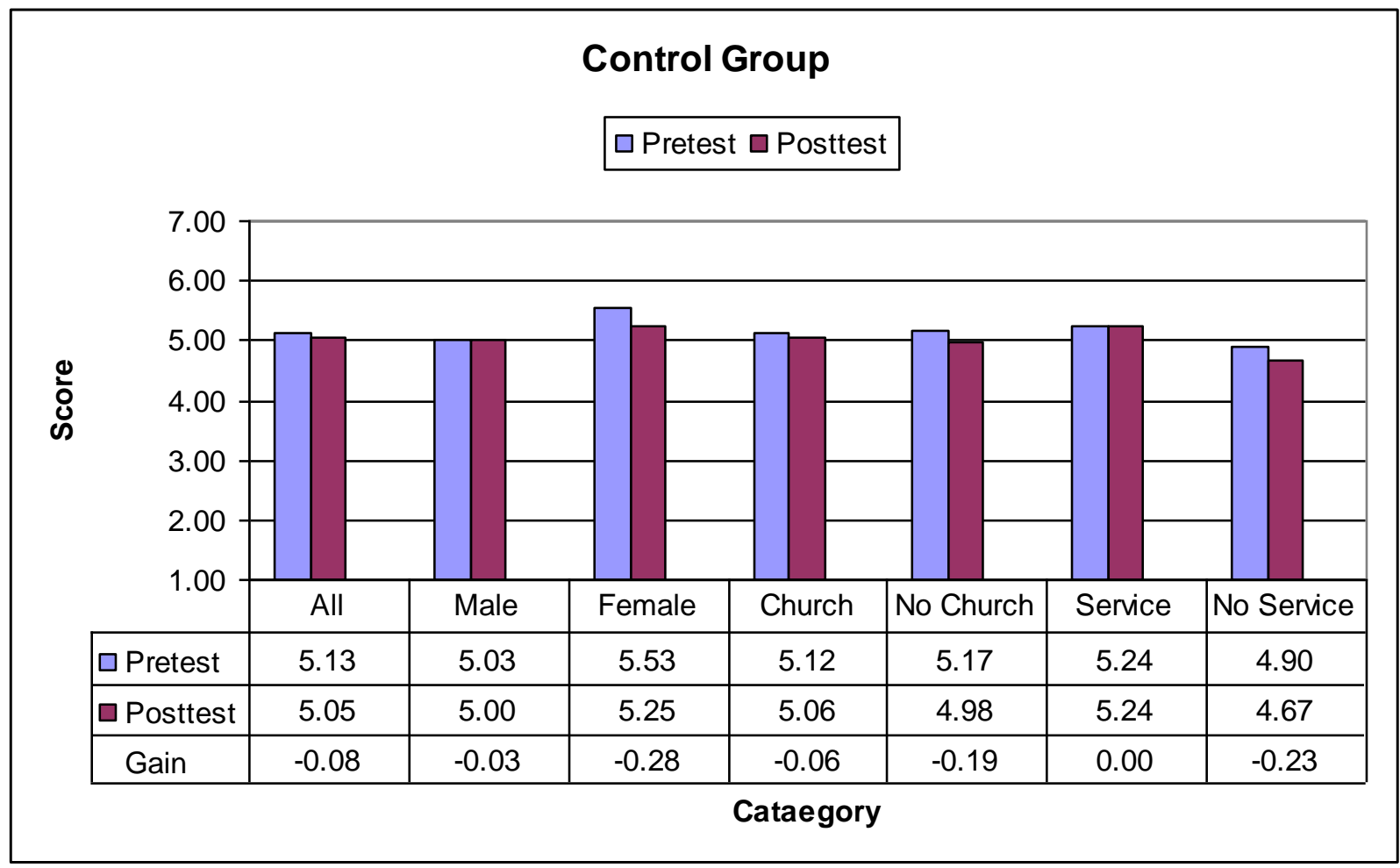

Figure 2: Experimental Group

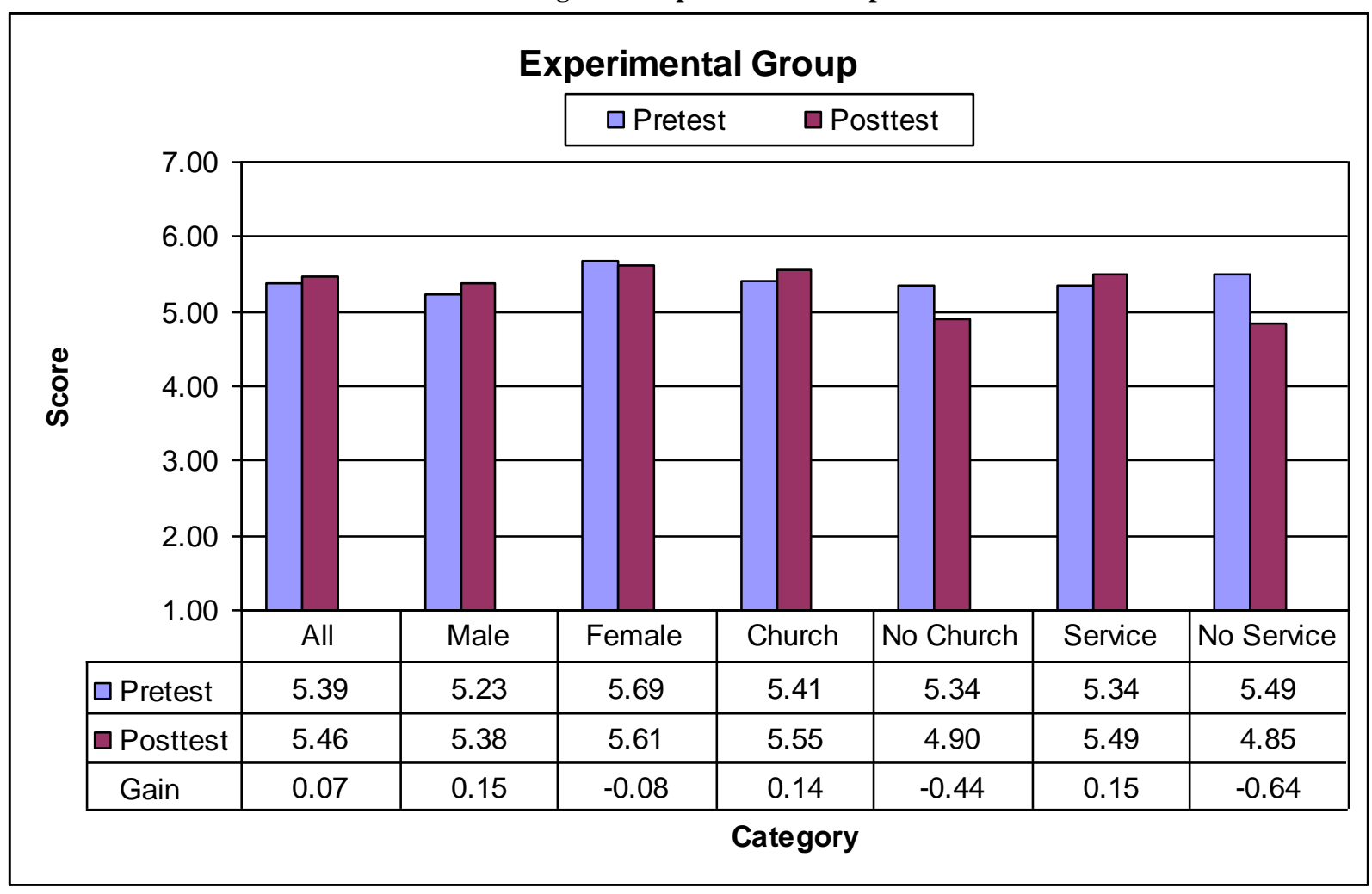


Figure 3: Difference In Gain Scores

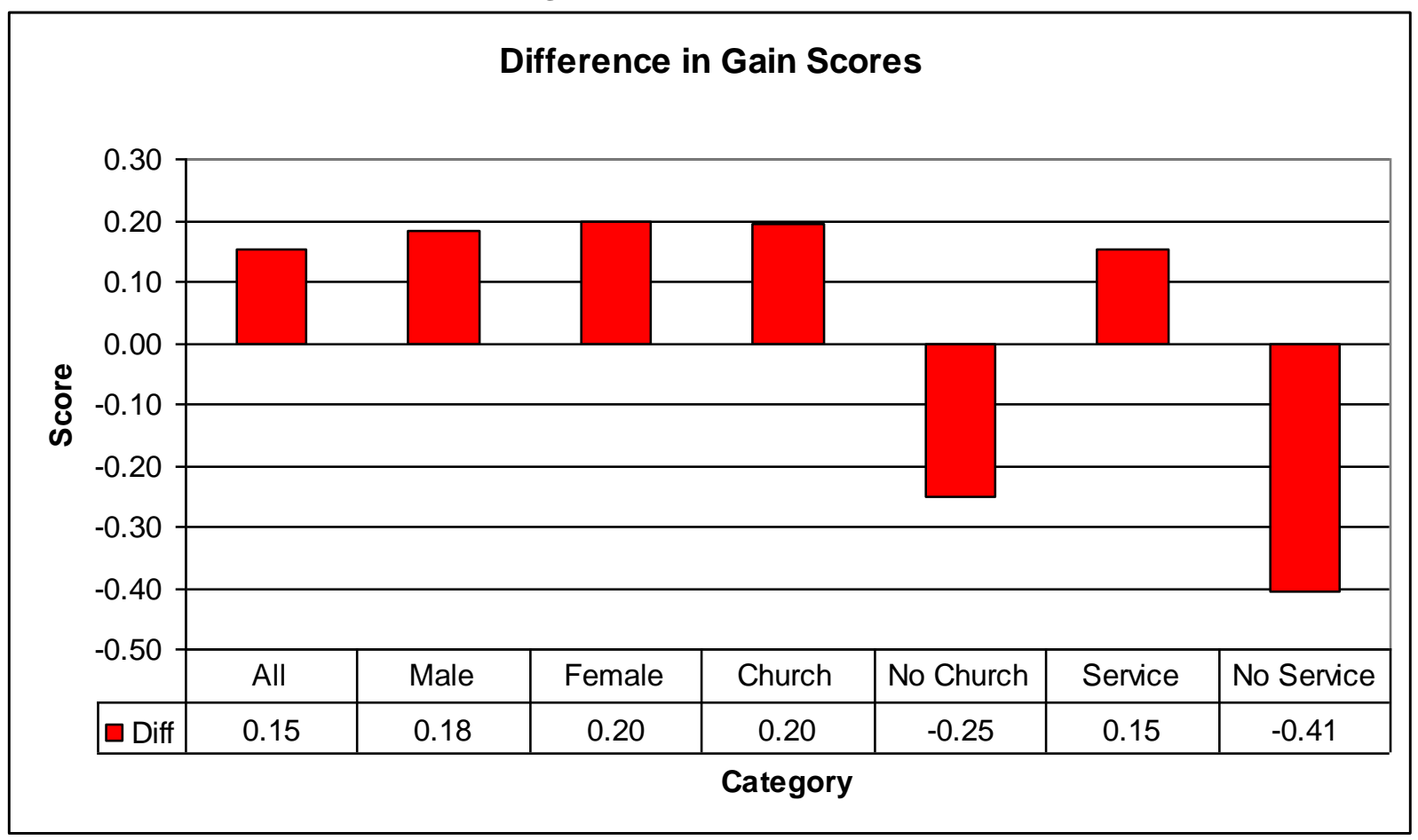

\section{DISCUSSION}

Our results are consistent with other intervention studies. Moral education during the college years works. Based on a meta-analysis of 172 studies using the DIT, King and Mayhew (2002:248) report that "dramatic gains in moral judgments are associated with collegiate participation." In our experiment, classroom interventions in the form of short ethics lectures and discussions of ethical dilemmas significantly increased the moral judgment scores.

Based on this result, ethical education across the accounting curriculum appear to be an effective way to increase the moral reasoning of accounting students. This conclusion supports the recommendation of Armstrong (1993) who advocates that ethics be taught both in existing accounting courses with case studies (as done in our experiment) and in separate courses at the start and end of the accounting curriculum. In the curriculum at our school, all students are required to take one course with a significant ethics component before starting the courses in their major.

The results were sensitive to prior church attendance, prior community service experience, and gender differences. Our results were consistent with the gender differences reported on DIT studies, where the average scores of females are higher than the average scores of males. However, we found that the moral judgment of the females did not increase significantly $(\mathrm{p}=0.056)$. It may be that the males had more service involvement than the females and were more influenced by the ethics training. Many of our male students have completed a two-year mission experience for their church. The mission experience included mandatory community service each week. In comparison, few of our female students had a mission experience. We speculate that the mission experience of the males contributed to the difference in the gain scores. Unfortunately, our small sample size prevents us from formally testing this possibility. However, the mean pretest score of our students was significantly larger than the mean score of students tested on the same instrument by Conroy and Emerson (2004), suggesting that our students were at a higher level of ethical awareness. A possible explanation for the difference is the mission experience. 


\section{CONCLUSION}

The credibility of the accounting profession is under attack. Some authors have suggested that the ethics education provided to accounting students is inadequate (Albrecht and Sack 2000, Madison 2002, Etzioni 2002), and call for a renewed emphasis in the accounting curriculum. Our experiment shows that ethics education in the form of ethics lectures and discussions of short ethical dilemmas during the semester can significantly improve the moral judgment of accounting students, especially those with prior church or service experiences.

\section{REFERENCES}

1. Albrecht, W. and R. Sack. 2000. Accounting education: charting the course through a perilous future. Accounting Education Series 16. Sarasota, FL: American Accounting Association.

2. Armstrong, M. 1987. Moral development and accounting education. Journal of Accounting Education 5: 2743.

3. Armstrong, M. 1993. Ethics and professionalism in accounting education: a sample course. Journal of Accounting Education 11: 77-92.

4. Boss, J. 1994. The Effect Of Community Service Work On The Moral Development Of College Ethics Students. Journal of Moral Education 23: 183-198.

5. Campbell, D. and J. Stanley. 1966. Experimental and Quasi-experimental Designs for Research. Chicago, IL: Rand-McNally College Publishing Company.

6. Conroy, S. and T. Emerson. 2004. Business ethics and religion: religiosity as a predictor of ethical awareness among students. Journal of Business Ethics 50: 383-396.

7. Etzioni, A. 2002. When it comes to ethics, b-schools get an $\mathrm{f}$. The Washington Post (4 August): B.04.

8. Financial Accounting Standards Board. 1993. Statements of Financial Accounting Concepts. Homewood, IL: Irwin.

9. Ferrell, O., J. Fraedrich, and L. Ferrell. 2005. Business Ethics. $6^{\text {th }}$ Edition. Boston, MA: Houghton Mifflin.

10. Good, J. and C. Cartwright. 1998. Development of moral judgment among undergraduate university students. College Student Journal 32: 270-276.

11. Gorman, M., J. Duffy, and M. Heffernan, M. 1994. Service experience and the moral development of college students. Religious Education 89: 422-431.

12. Hanson, K. 1987. What good are ethics courses? Across the Board (September): 10-11.

13. Institute of Management Accounting. 2000. Standards of Ethical Conduct for Practitioners of Management Accounting and Financial Management. Montvale, NJ: Institute of Management Accountants.

14. Jeffrey, C. 1993. Ethical development of accounting students, non-accounting business students, and liberal arts students. Issues in Accounting Education 8 (Spring): 87-96.

15. King, P. and M. Mayhew. 2002. Moral judgment development in higher education: insights from the defining issues test. Journal of Moral Education 31: 248-270.

16. Kohlberg, L. 1979. The Meaning and Measurement of Moral Development. Worchester, MA: Clark University Press.

17. Kohlberg, L. 1984. Essays on Moral Development: The Nature and Validity of Moral Stages. San Francisco, CA: Harper and Row.

18. Madison, R. 2002. Is failure to teach ethics the causal factor? Strategic Finance (December).

19. McDonald, G. and G. Donleavy. 1995. Objections to the teaching of business ethics. Journal of Business Ethics 14: 839-854.

20. McNeel, S. 1994. College teaching and student moral development, in Moral Development in the Professions: Psychology and Applied Ethics, ed. J. Rest and D. Narvaez (Hillsdale, NJ: Lawrence Erlbaum Associates): 26-47.

21. Miesing, P. and J. Preble. 1985. A comparison of five business philosophies. Journal of Business Ethics 4: 465-476.

22. Mustapha, S. and J. Seybert. 1989. Moral reasoning in college students: effects of two general education curricula, Educational Research Quarterly 14: 32-40.

23. Pascarella, E. and P. Terenzini. 1991. How college affects students: findings and insights from twenty years of research. San Francisco, CA: Jossey-Bass. 
24. Piper, T., M. Gentile., and S. Parks. 1993. Can Ethics be Taught? Cambridge, MA: Harvard Business School Press.

25. Ponemon, L. 1990. Ethical judgments in accounting: a cognitive-developmental perspective. Critical Perspectives on Accounting 1: 191-215.

26. Ponemon, L. 1993. Can ethics be taught in accounting? Journal of Accounting Education 11: 185-209.

27. Rest, J., D. Narvaez, M. Bebeau, and S. Thoma. 1999. Postconventional Moral Thinking: A neo-Kohlbergian Approach. Mahwah, NJ: Erlbaum Publishers.

28. Rest, J. and S. Thoma. 1985. Relationship of moral judgment development to formal education. Development Psychology 21: 709-714.

29. Rest, J. and D. Deemer. 1986. Life experiences and developmental pathways, in Moral Development: Advances in Research and Theory, ed. J.Rest. New York: NY: Praeger Press.

30. Sheskin, D. 2000. Handbook of parametric and nonparametric statistical procedures. $2^{\text {nd }}$ edition. New York: CRC Press.

31. Siu, N., J. Dickinson, and Y. Lee. 2000. Ethical evaluations of business activities and personal religiousness. Teaching Business Ethics 6: 393-410.

32. Smith, C. and C. Bunting. 1999. The moral reasoning of two groups of college students. Research in Education 62: 72-74.

33. Smith, P. and E. Oakley. 1997. Gender-related differences in ethical and social values of business students: implications for management. Journal of Business Ethics 16: 37-45.

34. Snodgrass, J. and R. Behling. 1996. Differences in moral reasoning between college and university business majors and non-business majors. Business and Professional Ethics Journal 15: 79-84.

35. St. Pierre, K., E. Nelson, and A. Gabbin, A. 1990. A study of ethical development of accounting majors in relation to other business and non-business disciplines. Accounting Educators' Journal 3: 23-35.

36. Tennant, S. 1991. Personal and moral development: a developmental curriculum intervention of liberal arts freshman. Dissertation Abstracts International 51: 2657A.

37. Thomas, C. 2004. An inventory of support materials for teaching ethics in the post-enron era. Issues in Accounting Education 19 (February): 27-52.

38. Thorne, L. 2000. The development of two measures to assess accountants' prescriptive and deliberative moral reasoning. Behavioral Research in Accounting 12: 139-169.

39. Weber, J. and S. Glyptis. 2000. Measuring the impact of a business ethics course and community service experience on students' values and opinions. Teaching Business Ethics 4: 341-358.

40. Wei, L. 2002. Enron collapse lets academics discuss ethics - accounting professors focus on new perceptions of a noble profession. Wall Street Journal (February 13): B.9.G. 


\section{ETHICAL AWARENESS QUESTIONNAIRE}

Instructions: Please indicate the degree to which you feel the behavior described in each vignette is ethically acceptable by circling the appropriate number on the seven-point scale, where $1=$ always acceptable and $7=$ never acceptable.

\begin{tabular}{|c|c|c|c|c|c|c|c|}
\hline Vignette & & & ase & Cir & $\operatorname{le} 0$ & & \\
\hline $\begin{array}{l}\text { 1. An executive earning } \$ 100,000 \text { a year padded his expense account by about } \\
\$ 3,000 \text { a year. }\end{array}$ & 1 & 2 & 3 & 4 & 5 & 6 & 7 \\
\hline $\begin{array}{l}\text { 2. In order to increase profits of the firm, a general manager used a production } \\
\text { process that exceeded legal limits for environmental pollution. }\end{array}$ & 1 & 2 & 3 & 4 & 5 & 6 & 7 \\
\hline $\begin{array}{l}\text { 3. Because of pressure from his brokerage firm, a stockbroker recommended a type } \\
\text { of stock that he did not consider to be a good investment. }\end{array}$ & 1 & 2 & 3 & 4 & 5 & 6 & 7 \\
\hline $\begin{array}{l}\text { 4. A small business received one-fourth of its gross revenue in the form of cash. The } \\
\text { owner reported only one-half of the cash receipts for income tax purposes. }\end{array}$ & 1 & 2 & 3 & 4 & 5 & 6 & 7 \\
\hline $\begin{array}{l}\text { 5. A company paid a } \$ 350,000 \text { "consulting" fee to an official of a foreign country. In } \\
\text { return, the official promised assistance in obtaining a contract that will produce } \\
\$ 10 \text { million profit for the contracting firm. }\end{array}$ & 1 & 2 & 3 & 4 & 5 & 6 & 7 \\
\hline $\begin{array}{l}\text { 6. A company president found that a competitor had made an important scientific } \\
\text { discovery that would sharply reduce the profits of his own company. He then } \\
\text { hired a key employee of the competitor in an attempt to learn the details of the } \\
\text { discovery. }\end{array}$ & 1 & 2 & 3 & 4 & 5 & 6 & 7 \\
\hline $\begin{array}{l}\text { 7. A highway-building contractor deplored the chaotic bidding situation and } \\
\text { cutthroat competition in his industry. He therefore reached an understanding with } \\
\text { other major contractors to permit bidding which would provide them with a } \\
\text { reasonable profit. }\end{array}$ & 1 & 2 & 3 & 4 & 5 & 6 & 7 \\
\hline $\begin{array}{l}\text { 8. A company president recognized that sending expensive Christmas gifts to } \\
\text { purchasing agents might compromise their position. However, he continued the } \\
\text { policy since it was common practice and changing it might result in a loss of } \\
\text { business. }\end{array}$ & 1 & 2 & 3 & 4 & 5 & 6 & 7 \\
\hline $\begin{array}{l}\text { 9. A corporate director learned that his company intended to announce a stock split } \\
\text { and increase its dividend. On the basis of this information, he bought additional } \\
\text { shares and then following the announcement sold them for a gain. }\end{array}$ & 1 & 2 & 3 & 4 & 5 & 6 & 7 \\
\hline $\begin{array}{l}\text { 10. A corporate executive promoted a loyal friend and competent manager to the } \\
\text { position of divisional vice president in preference to a better-qualified manager } \\
\text { with whom he had no close personal ties. }\end{array}$ & 1 & 2 & 3 & 4 & 5 & 6 & 7 \\
\hline $\begin{array}{l}\text { 11. An engineer discovered what he perceived to be a product design flaw that } \\
\text { constituted a safety hazard. His company declined to correct the flaw. The } \\
\text { engineer decided to keep quiet, rather than taking his complaint outside the } \\
\text { company. }\end{array}$ & 1 & 2 & 3 & 4 & 5 & 6 & 7 \\
\hline $\begin{array}{l}\text { 12. A comptroller selected a legal method of financial reporting which concealed } \\
\text { some embarrassing financial facts that would otherwise have become public } \\
\text { knowledge. }\end{array}$ & 1 & 2 & 3 & 4 & 5 & 6 & 7 \\
\hline $\begin{array}{l}\text { 13. An employer received application for a supervisor's position from two equally } \\
\text { qualified applicants but hired the male applicant because he thought that some } \\
\text { employees might resent being supervised by a female. }\end{array}$ & 1 & 2 & 3 & 4 & 5 & 6 & 7 \\
\hline $\begin{array}{l}\text { 14. As part of the marketing strategy for a product, the producer changed its color and } \\
\text { marketed it as "new and improved," even though its other characteristics were } \\
\text { unchanged. }\end{array}$ & 1 & 2 & 3 & 4 & 5 & 6 & 7 \\
\hline $\begin{array}{l}\text { 15. Facing large clean-up costs, a mining company that produces arsenic as a by- } \\
\text { product of its regular operations hired research consultants to show that the safe } \\
\text { level of arsenic in drinking water is higher than previously believed. }\end{array}$ & 1 & 2 & 3 & 4 & 5 & 6 & 7 \\
\hline
\end{tabular}




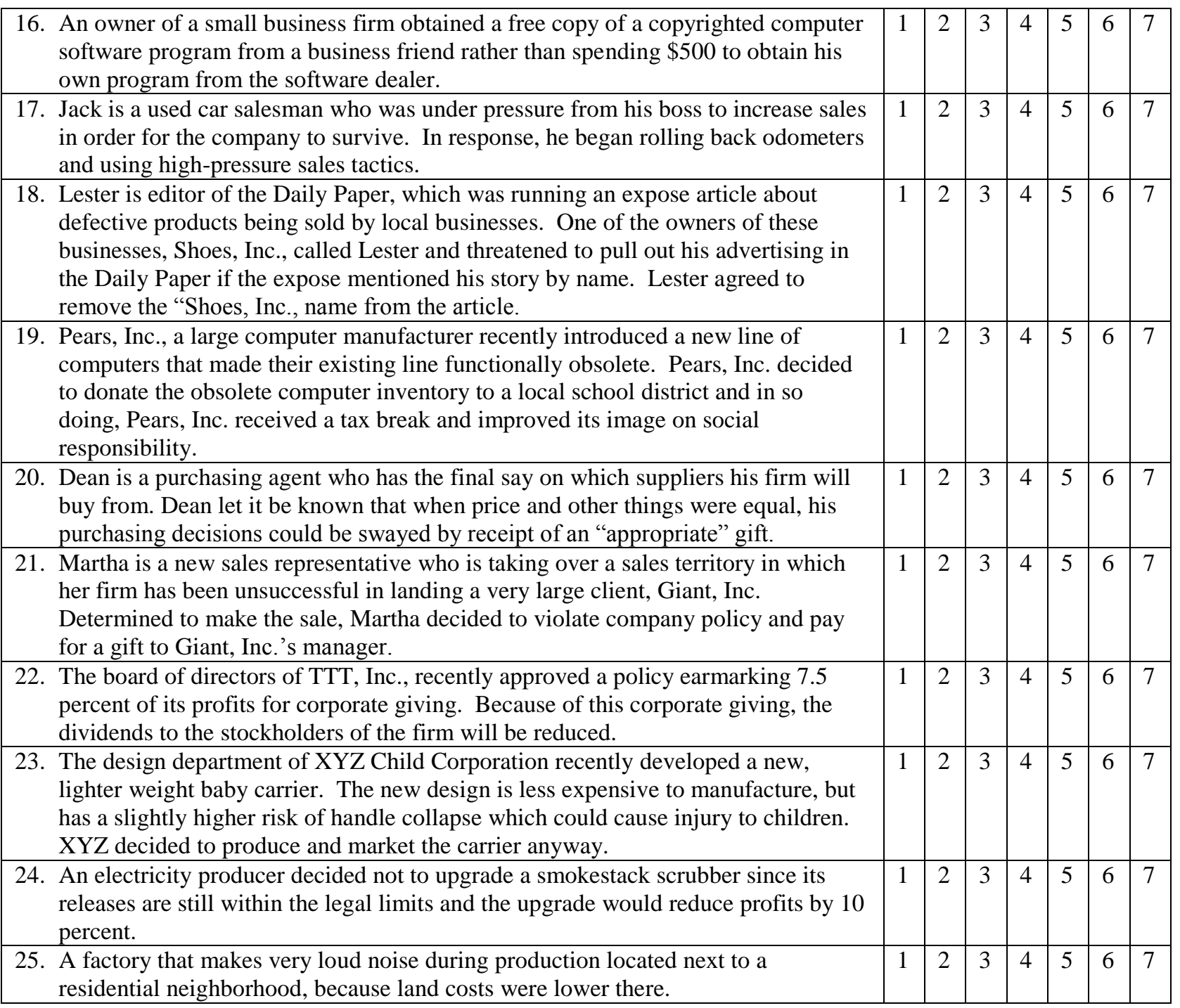

\begin{tabular}{|l|c|c|}
\hline Demographics & \multicolumn{2}{|c|}{ Please Circle One } \\
\hline 1. $\quad$ Please indicate your gender & Male & Female \\
\hline 2. Do you generally attend church weekly? & Yes & No \\
\hline 3. Have you had any significant community service experience? & Yes & No \\
\hline $4 . \quad$ Please enter your full name & \multicolumn{2}{|}{} \\
\hline
\end{tabular}

